\title{
Methandrostenolone Measurement
}

National Cancer Institute

\section{Source}

National Cancer Institute. Methandrostenolone Measurement. NCI Thesaurus. Code C75382.

The determination of the amount of methandrostenolone present in a sample. 